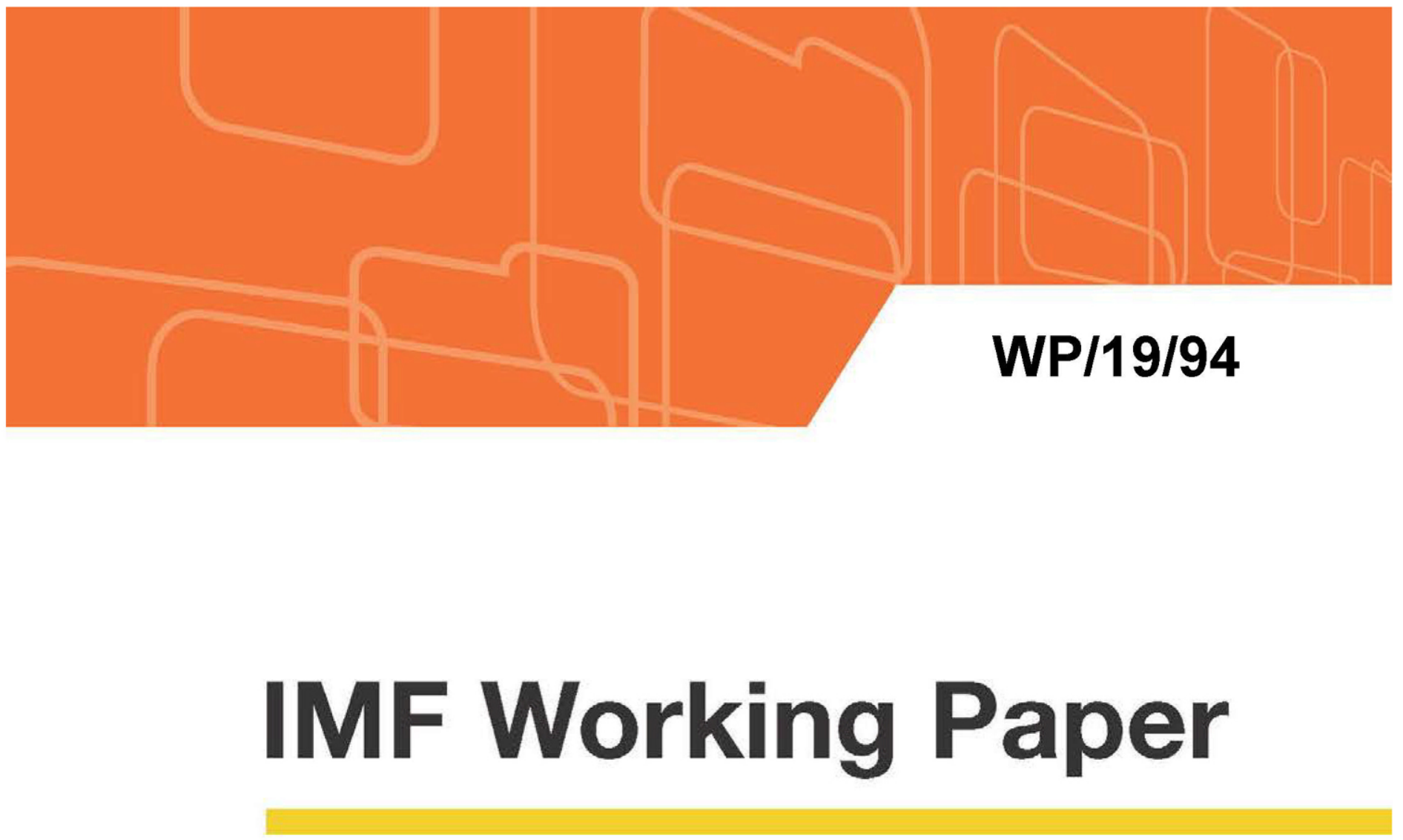

\title{
Taming Financial Development to Reduce Crises
}

by Sami Ben Naceur, Bertrand Candelon and Quentin Lajaunie

IMF Working Papers describe research in progress by the author(s) and are published to elicit comments and to encourage debate. The views expressed in IMF Working Papers are those of the author(s) and do not necessarily represent the views of the IMF, its Executive Board, or IMF management. 


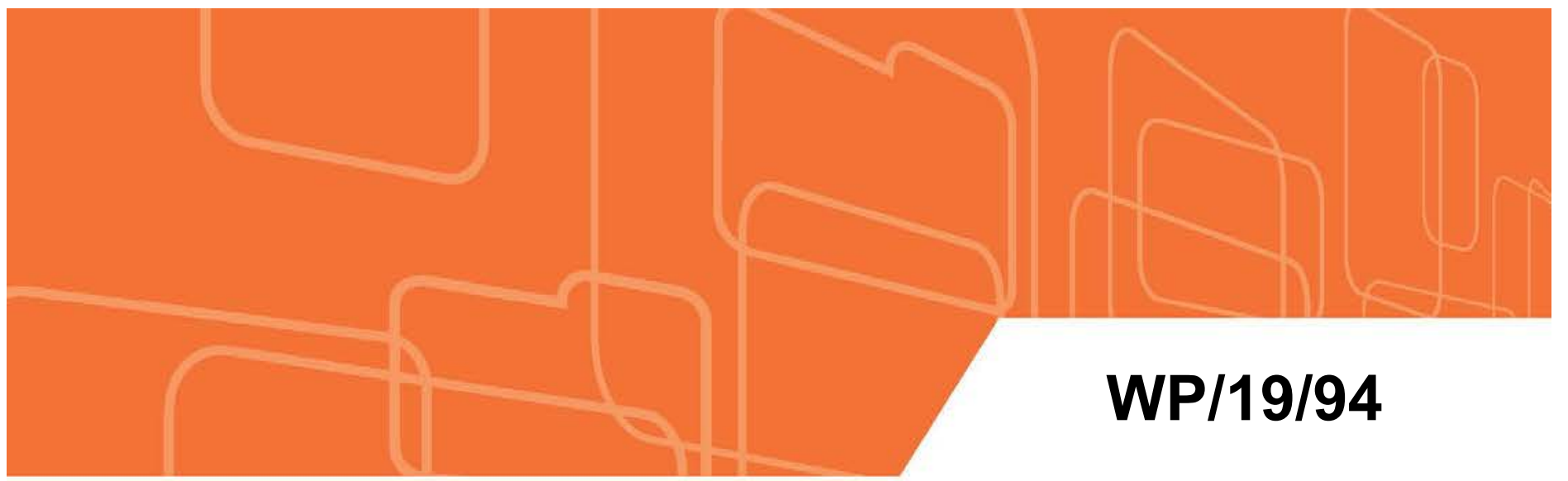

\section{IMF Working Paper}

\section{Taming Financial Development to Reduce Crises}

by Sami Ben Naceur, Bertrand Candelon and Quentin Lajaunie

IMF Working Papers describe research in progress by the author(s) and are published to elicit comments and to encourage debate. The views expressed in IMF Working Papers are those of the author(s) and do not necessarily represent the views of the IMF, its Executive Board, or IMF management.

I N T E R N A T I O N A L M O N E T A R Y F U N D 


\title{
IMF Working Paper
}

Institute for Capacity Development

\section{Taming Financial Development to Reduce Crises \\ Prepared by Sami Ben Naceur, Bertrand Candelon and Quentin Lajaunie ${ }^{i}$}

Authorized for distribution by Norbert Funke

April 2019

\section{IMF Working Papers describe research in progress by the author(s) and are published to elicit comments and to encourage debate. The views expressed in IMF Working Papers are those of the author(s) and do not necessarily represent the views of the IMF, its Executive Board, or IMF management.}

\begin{abstract}
This paper assesses whether and how financial development triggers the occurrence of banking crises. It builds on a database that includes financial development as well as financial access, depth and efficiency for almost 100 countries. Through estimation of a dynamic logit panel model, it appears that financial development, from an institutional dimension and to a lesser extent from a market dimension, triggers financial instability within a one- to two-year horizon. Additionally, whereas financial access is destabilizing for advanced countries, it is stabilizing for emerging and low income ones. Both results have important implications for macroprudential policies and financial regulations.

Keywords: Financial Development, Banking crises, Regulation

JEL Classification Numbers: C33, G01, G18

\footnotetext{
i Sami Ben Naceur (International Monetary Fund), Bertrand Candelon (Université Catholique de Louvain and Maastricht University), Quentin Lajaunie (Université Paris Dauphine). The authors thank Juliana Araujo, Norbert Funke, Nigel Nagarajan, Tim Rose, as well as the participants at the 1st Annual Conference of the JRC Community of Practice in Financial Research (CoPFiR) for stimulating comments and questions. They also benefited from excellent research assistance on the data collection from Sena Oztosun and excellent administrative assistance from Elisa Manarinjara. This research has been conducted with the research program "Risk Management and Investment Strategies" under the aegis of the Europlace Institute of Finance, Insti7, and of ICD's Visiting Scholar program. The usual disclaimer applies: the views expressed here are those of the authors, and the paper does not represent the views of the IMF, its Executive Board or its management.

Email addresses: sbennaceur@imf.org (Sami Ben Naceur), candelonb@gmail.com (Bertrand Candelon), quentin_lajaunie@hotmail.fr (Quentin Lajaunie)
} 


\section{Table of Contents}

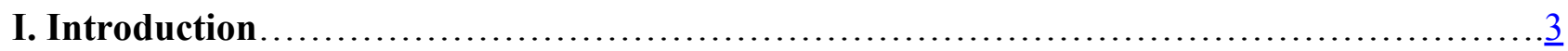

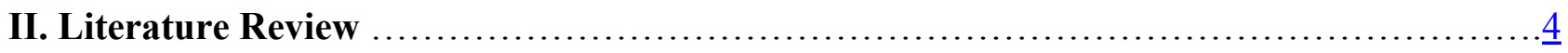

III. Methodology: The Dynamic Panel Logit Model......................................

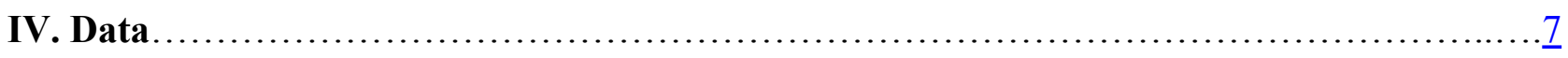

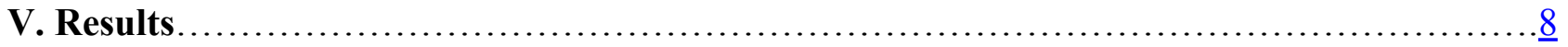

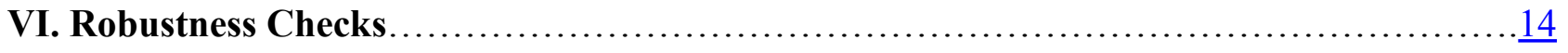

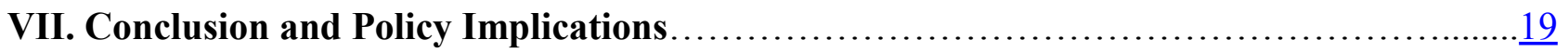

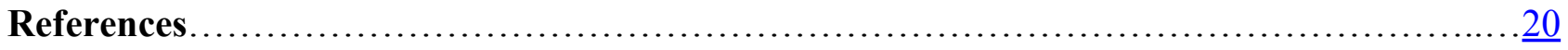

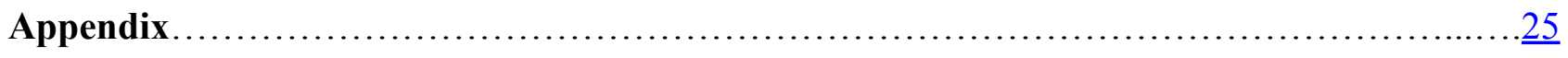

Tables

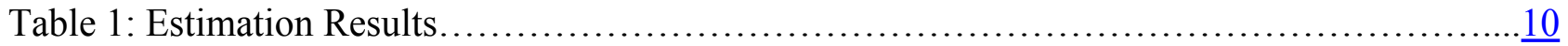

Table 2: Estimation Results - Advanced Economies..................................... $\frac{11}{11}$

Table 3: Estimation Results - Emerging Markets........................................

Table 4: Estimation Results - Low-Income Countries......................................13

Table 5: Estimation Results - Kaopen - NPL - Exchange Rate............................

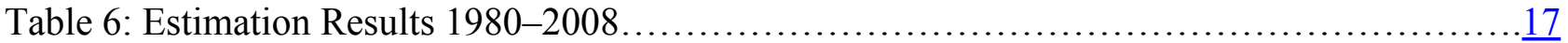

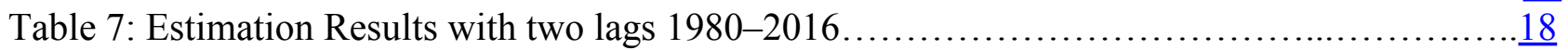

Table 8: Variable use for building the Financial Development Index........................

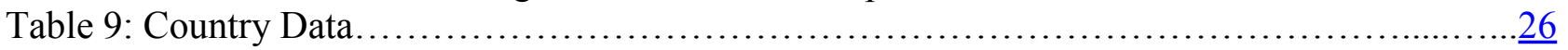




\section{INTRODUCTION}

Early writers have found that financial development has been associated with higher growth, lower inequality/poverty and reduced economic volatility (Levine, 2005). More recent literature has highlighted the vanishing effect of financial development on growth (Cecchetti and Kharoubi, 2012) and the existence of nonlinearities in the financial growth-nexus, showing that financial development starts lowering growth when a threshold of credit-to-private/GDP is crossed (Arcand et al., 2015).

This vanishing effect stems from financial deepening, rather than from better inclusion or higher efficiency (Sahay et al., 2015). Similarly, a large number of empirical studies have examined how financial development may generate future banking crises (cf. Demirguc-Kunt and Detragiache, 2005 or Cihak, 2007). The researchers all find that credit growth is the most important factor at the origin of banking crises. Still, these works are incomplete in two dimensions. First, contrary to the literature focusing on growth, these works include financial development through different aggregates or proxies, but they do not consider its different dimensions (depth, access and efficiency). Regulators are thus left with the option to limit or to facilitate financial development, enabling the precise targeting of which dimension (access, depth or efficiency) should be favored or limited. The practical implementation of optimal rules on financial development is thus impossible. Second, all these studies consider static binary models (probit/logit), whereas Kauppi and Saikkonen (2008) and more recently Candelon et al. (2014) have shown that this specification can be misleading if the banking crisis or the dependent variables exhibit persistence.

This paper aims to fill these two gaps. It considers a panel of 98 countries, for which the systemic banking crisis database of Leaven and Valencia (2013) has been extended to 2016. Following Svirydzenka (2016), the financial development variable is decomposed into 6 sub-indices, which measure depth, access and efficiency for both institutions and the market sector. Finally, the relationship between banking crises and the financial development indicators is analyzed using a dynamic panel logit model. It turns out that for the whole panel, financial development indeed increases the probability of the occurrence of a crisis. It can be via either financial institution development or to a lesser extent financial market development. Considering now three groups of countries clustered according to their degree of development, we observe that in advanced economies, depth (FID) and access (FIA) cause banking crises, whereas for least income developed countries (LIDC) and emerging markets (EM), only the financial institution's depth constitutes a leading indicator for future crises. In the latter case, access to financial services enhances financial stability, whereas it should be limited in developed countries.

These findings convey important messages to regulators. The results first confirm the potential destabilizing effect of financial development leading to systemic banking crises. The findings hence support the implementation of regulatory measures, such as capital requirements and access control to loans and deposits for financial institutions, in order to stabilize the system. Second, the results show that regulation should not be unique but that it should take into account the degree of development of the country. Whereas access to financial institutions is destabilizing for advanced countries (increasing, for example, the amount of nonperforming loans), it is stabilizing for other countries (of middle and low income) via the promotion of financial inclusion and the reduction of inequalities. Regulators should thus impose strict access control for financial intermediaries in advanced countries. In contrast, regulators should enhance its access, supporting for example, fintech industry and its financial innovations (mobile application payments, etc.) in low-income countries. The 
paper is composed as follows. In Section II, a literature review is presented. Section III deals with the methodology. Section IV describes the database. Section V exhibits the empirical results for the whole sample of countries as well as for 3 clusters of countries. Section VI provides several robustness checks, and Section VII exposes the consequences for regulators and concludes.

\section{LITERATURE REVIEW}

The literature on financial development started with consideration of the relationship between financial deepening and economic growth. Three theoretical views dominated the debate: Schumpeter (1934), Goldsmith (1969), McKinnon (1973) and Shaw (1973) viewed finance as an engine of growth through the encouragement of innovation (the "supply-leading view"). Robinson (1952) argued that growth drives financial development by increasing demand for financial services (the "demand-following view"). Lucas (1988) described the contribution of financial development to growth as overstated. The endogenous growth theory has also attracted interest in the finance and growth nexus (see Greenwood and Jovanovic, 1990 and Bencivenga, 1991 for the role of the financial system in fostering efficient allocation of resources; Saint-Paul, 1992 for the role of the financial sector in reducing risk; and Rousseau and Wachtel, 2000 for the exit mechanisms provided by stock markets).

The contribution of finance to growth has also received considerable attention empirically. Goldsmith (1969) was the first to document a positive correlation between financial intermediaries, development, and growth. A large number of empirical studies have followed, using a wide array of econometric techniques such as cross-sectional, time-series, panel, industry-level, and firm-level data and controlling for biases arising from omitted variables and endogeneity. The authors find that financial development (banks and stock markets) generates larger economic growth, consistent with the proposition of "more finance, more growth."

Some recent studies, however, emphasize the nonlinearity of the relationship between finance and growth demonstrating that this relationship varies with the levels of income, financial development and inflation. Rioja and Valev (2004a) show that finance impacts growth positively and significantly in middle-income countries but weakly in high-income countries. Rioja and Valev (2004b) find that the effect of financial development on growth is positive only in the intermediate and very high financial development groups. Rousseau and Wachtel (2000) find that growth is not affected by financial development when inflation exceeds 13 percent.

The Global Financial Crisis of 2007-2008 has led both researchers and policymakers to question the prior conclusion of "more finance is better." Cecchetti and Kharoubbi (2012), Law and Singh (2014), and Arcand et al. (2015) uncover an inverted U-shaped relationship between financial development and growth, which shows a turning point (around 90-110\% of GDP) where the effect of finance on growth stops being positive. These findings reveal that sizeable and fast-growing financial sectors may not necessarily be good for economic growth because they compete with the real sector for the same resources. Beck (2012) proposes several explanations for the nonlinearities and the vanishing effect of financial development on growth (Wachtel, 2011). First, the measures of financial development used in the literature might not capture the quality of the financial system and the non-

${ }^{1}$ see Levine (2005) for a review 
intermediation activities of the financial sector. Second, when an economy catches up and comes close to the productivity frontier, the financial sector stops contributing positively to growth (Aghion et al., 2005). Third, Beck et al. (2012) find that only enterprise credit contributes to growth and that most financial development in high-income countries comes from household credit, which might explain the absence of a positive impact of finance on growth in advanced economies. Fourth, fast-growing and oversized financial sectors attract the brightest young talent to the detriment of the real sector (Philippon, 2010). Finally, an overly large and risky financial system resulting from an overgenerous financial safety net is prone to more frequent financial crises.

The previous literature on the finance-growth nexus overlooked the issue of whether a larger financial system is associated with a higher occurrence of economic crises. In the 1980s and 1990s, many developed economies and developing countries witnessed a wave of costly systemic banking crises. Since the mid-1990s, the prediction of financial crises has become the subject of a large number of studies. The literature has also offered a number of theories explaining why finance can lead to financial crises. Bernanke and Blinder (1988) and Kiyotaki and Moore (1997) argue that the quantity of credit in the economy is positively associated with the probability of a banking crisis. Minsky (1986) explains that an extended period of financial stability encourages excess borrowing which may lead to a banking crisis. Keeley (1990) and Dell'Ariccia and Marquez (2004) argue that financial liberalization comes with more competition and a lower standard of lending, which can lead to an increase in lending to lower quality borrowers and a higher probability of banking crises.

The empirical literature on early warning systems (EWS) for systemic banking crisis has come up with two main approaches: the signal approach and the binary regression approach. The signal approach identifies individual variables that best signal a threat to financial stability (Kaminski and Reinhart, 1999; Borio and Drehmann, 2009; Drehmann and Juselius, 2014). The second approach, the binomial or multinomial logit or probit, relates a binary banking crisis dummy to multiple explanatory variables to predict banking crises (Demirguc-Kunt and Detragiache, 1998, 2000, 2002; Davis et al., 2011; Schularick and Taylor, 2012; and Duca and Peltonen, 2013). Davis and Karim (2008a, 2008b) suggest that the logit approach outperforms the signaling approach because the former exhibits lower Type I (missed crises) and Type II (false alarms) errors compared to the latter. The literature has proposed various early warning indicators such as a high inflation rate, a large current account deficit, house price inflation, an increase in the real interest rate, and excessive domestic credit (see Kauko (2014) for a review). We will focus on the credit variables (measures of financial deepening) as banking crisis determinants, since our interest is to examine the impact of financial development on banking crises.

Two kinds of credit variables have often been considered as banking crisis early warning indicators, namely, the credit-to-GDP ratio and the credit growth rate. Demirguc-Kunt and Detragiache (1998, 2005) find that the level of the credit-to-GDP ratio and the growth rate of credit have a robust positive effect on bank crisis occurrences. Sahay et al. (2015) find that a faster pace of financial deepening increases financial instability when the financial system is weakly regulated and supervised. In contrast, Davis and Karim (2008), in replicating the Demirguc-Kunt and Detragiache (2005) analysis on a larger sample and a longer period, find that the credit-to-GDP ratio is not a good predictor of banking crises. This resultwas confirmed by Hahm et al.(2013) and von Hagen and Ho (2007). Rose and Spiegel (2011) also concluded that the ratio of credit relative to GDP was of no use as a predictor of the Global Financial Crisis of 2007-2008. In a recent paper, Mathonnat and Minea (2018) revisited these conflicting findings using a large sample of banking crises and five 
financial development variables, finding that the level of the credit-to-GDP ratio jointly introduced with its growth and volatility does not affect significantly the occurrence of banking crises. The lagged value of the other credit variable, the growth rate of credit, has been tested as a bank crisis predictor. Jorda et al. (2011), Schularick and Taylor (2012), Demerguc-Kunt and Detrigriache (2005), Kaminski et al. (1998, 1999) and Bordo and Meissner (2012), among others, show that credit growth lagged two years and up is a good predictor of crises. Bunda and Ca'Zorzi (2010) and Barrell et al. (2011) conclude that credit growth lagged one year is of no use as a crisis predictor. Buyukkarabacak and Valev (2010) decompose private credit into household credit and enterprise credit. They find that a rapid expansion of household credit is a significant predictor of banking crises. Mathonnat and Minea (2018) used instead monetary aggregate growth and found that the growth of M3/GDP impacts positively and significantly the probability of a banking crisis. Drehmann et al. (2011) substituted the growth rate of credit by the trend deviation of the credit-to-GDP ratio and found evidence that this variable is the best of ten different potential variables to predict banking crises, confirming Borio and Lowe's (2002) initial conclusion suggesting that a credit-to-GDP trend deviation reaches its peak three years before the occurrence of a banking crisis.

\section{Methodology: The Dynamic PANel Logit Model}

The methodology employed in this paper builds on the dynamic panel logit version proposed by Kauppi and Saikkonen (2008) and Candelon et al. (2014).

Let us denote by $\left\{y_{i, t}\right\}_{t=1}^{T}$ the banking crisis binary variable for country $i, i \in\{1,2, \ldots N\}^{2}$, which takes the value 1 during crisis periods and 0 otherwise. Similarly, $\left\{x_{i, t}\right\}_{t=1}^{T}$ represents the matrix composed of the $k$ explanatory variables, which are the indicators of financial development and the macroeconomic control variables in our case.

The dynamic panel logit model has the following form:

$$
\operatorname{Pr}\left(y_{i t}=1\right)=F\left(\pi_{i, t}\right)=F\left(\alpha y_{i, t-1}+x_{i, t-1} \beta+\delta \pi_{i, t-1}+\eta_{i}\right), \text { for } t=1,2, \ldots T, \text { and } i=1,2, . . N \text {, }
$$

where $N$ is the number of countries; $\operatorname{Pr}_{t-1}\left(y_{t}=1\right)$ is the conditional probability of observing a banking crisis given the information set we have at our disposal at time $t-1$; and $\pi_{t}$ is the index at time $t$. $F$ is the logistic c.d.f., which is preferred to the Gaussian one, as it is more appropriate for the study of extreme events such as crises. $\eta_{i}$ is a country fixed effect for the control of unobserved heterogeneity and potential bias. The coefficient $\beta$ informs us about the one-step-ahead causal relationship between the explanatory variables (financial development proxies and/or the macroeconomic variables) and the banking crises. If the sign is positive (resp. negative) it indicates that the probability of occurrence of a crisis in a horizon of one year will increase (resp. decrease). The dynamic of the crisis is captured by the coefficients $\alpha$ and $\pi$. $\alpha$ is associated with the lagged binary banking crisis variable, whereas $\pi$ is linked to the lagged index. Both terms capture the persistence of the crisis and constitute the innovation proposed by Kauppi and Saikkonen (2008).

\footnotetext{
${ }^{2}$ For ease of notation, the country index $i$ is omitted hereafter.
} 
If one of them is significantly different from 0 , then it implies that the traditional static logit models are biased and that their interpretations may be misleading. Candelon et al. (2014) show that the different alternatives of this general model can be estimated under the same exact maximum likelihood (EML) framework.

To be more precise, the log-likelihood function has the following general form:

$\log \mathrm{L}\left(\theta, \eta_{i}\right)=\sum_{i=1}^{N} \log \mathrm{L}_{i}\left(\theta, \eta_{i}\right)=\sum_{i=1}^{N} \sum_{t=1}^{T}\left[y_{i t} \log \left(F_{i t}\right)+\left(1-y_{i t}\right) \log \left(1-F_{i t}\right)\right]$,

where $\theta$ represents the vector of parameters.

The EML estimators have the desired large-sample properties. As shown in Candelon et al. (2014), 4 different models can be considered, each of which correspond to particular restrictions of the general log-likelihood function.

The first model is the static logit model. In such a case $\alpha=\pi=0$. Only the exogenous macroeconomic variables affect the future occurrence of a banking crisis. The second and third models are dynamic and include either the lagged value of the binary dependent variable $y_{t-1}$ or the lagged index $\pi_{t-1}$. Finally, the most complex dynamic model combines the two previous cases and includes both the lagged dependent variable $y_{t-1}$ and the lagged index $\pi_{t-1}$. The best model is chosen as the one minimizing the Bayesian information criterion (BIC).

Finally, since we do not make any assumptions about the distribution of $\left\{\eta_{i}\right\}_{i=1}^{N}$, they are treated as parameters to be estimated, and our approach is a fixed effects one. In addition, we assume no crosssectional dependence. In such a case, we follow Candelon et al. (2014) and implement a correction à la Carro (2007).

\section{DATA}

For a long time, financial development has been measured by proxies such as the credit- to-GDP ratio or stock market capitalization (see Rajan and Zingales, 1998 or more recently Arcand et al., 2015). Still, financial development (FD) has evolved and is now multidimensional. In many countries, financial institutions (FI) have grown. Traditional players such as investment banks, insurance companies, mutual funds, pension funds, and venture capital firms are now in competition with many other types of nonbank financial institutions, which are now playing substantive roles. Additionally, it is possible to enter the markets bypassing these traditional institutions. Internet trading platforms allow you to directly invest your savings. This finance market (FM) is relatively important in the U.S. and developed countries, whereas so far it remains limited in low- and middle-income countries. An adequate index of financial development should encompass both of these dimensions. Recent studies (Cihak et al., 2012, Sahay et al., 2015) propose to disaggregate Financial development into different dimensions: depth (D), corresponding to the size and liquidity of the markets; access (A), measuring the ability of individuals and companies to access financial services; and efficiency (E), indicating the level of activity in capital markets and the ability of institutions to provide financial services at low cost and with sustainable revenues. We are thus left with 9 measures for financial development: the global one FD, composed of two sub- indices FI and FM, 
which are each finally decomposed into 6 individual indicators FID, FIA, FIE, FMD, FMA, and FME. Cihak et al, (2012) explain in detail how indices are built. The first step consists in building the 6 sub-indices FID, FIA, FIE, FMD, FMA, and FME. Each sub-index depends on a set of specific variables. For example, Financial Institutions Depth (FID) is a composite indicator including Private-sector credit, Pension fund assets, Mutual fund assets, and Insurance premiums, life and non-life. Appendix 1 provides a list of the variables considered for each sub-indices. The weights of each variable in the composite index is obtained via a principal component analysis (PCA). In a second step, once the sub-indices are built, indices FI and FM are also constructed via a PCA approach based on the sub-indices. In a final step the FD index is built from FI and FM. Svirydzenka (2016) followed this methodology to set up a global database for 183 countries covering the period 1980-2015 at an annual frequency.

For the banking crisis dummy, we use the Leaven and Valencia (2013) database, which encounters systemic financial market failures. As the sample size only covers the period until 2011, we complete it for the period 2012-2016 with the database of Candelon et al. (2018). ${ }^{3}$ The banking crisis database thus contains 100 countries from 1980 to 2016 on a yearly basis ${ }^{4}$

The macroeconomic control variables retained are the output growth rate and the interest rate spread built as the difference between the 10 - year treasury rate and a 3 - month monetary rate. ${ }^{5}$ Both are yearly and extracted from the International Financial Statistics (IFS) database of the International Monetary Fund. In summary, our sample comprises 98 countries for the period $1980-2016$.

\section{RESULTS}

Table (1) reports the estimates of model (3), where the dependent variable is the systemic banking crisis index explained by different indicators of financial development and macrovariables. In this first exercise, all the countries are considered for the period 1980-2016.

We first notice that model (2) i.e., the one with a lag binary variable, presents in each case the lowest BIC and thus is always selected. ${ }^{6}$ This observation then confirms that considering a static logit model is not adequate and that the persistence should be introduced by the lagged binary variable, indicating that causality is nonlinear in essence. ${ }^{7}$ Macroeconomic control variables are always significant and exhibit the expected signs. Indeed, an increase in the output growth rate reduces significantly the probability of occurrence of a banking crisis at a horizon of one year. Similarly, an inversion of the yield curve, i.e., the negative interest rate spread(builtas the difference between the long and short interest rates), signals a higher risk of a banking crisis. When estimating

\footnotetext{
${ }^{3}$ They expand the sample to more countries and more years, up to 2016, using data from Harvard Business School (HBS) http://www.hbs.edu/faculty/initiatives/behavioral-finance-and-financial-stability/Pages/global.aspx.

${ }^{4}$ Appendix 2 provides a list of the countries as well as the date of banking crises. It also reports the country group they belong to.

${ }^{5}$ Several other control variables have been tested, as the concentration index in the financial sector (Lerner index). Besides being available only for a very restrictive number of countries, they turn out to be non-significant. For sake of space, they are not reported, but available from authors upon request.

${ }^{6}$ Results for models (1), (3) and (4) are not reported to save space but are available upon request from the authors.

${ }^{7}$ See Candelon and others (2013) foradiscussiononcausalityinbinarydynamic models. Evenifitisproposed in the case of multivariate model itcanbe easily translated to univariate ones.
} 
the panel for the 98 countries over the period 1980-2016, financial development appears to increase financial instability, increasing the probability of occurrence of a crisis in a one-year period (see model (1)). It can be via either the financial institution (model (2)) or the financial market development (model (3)). Concerning financial market development (models (4) and (6)), we observe an opposite effect between the depth and the access dimension. Whereas the financial institution's depth is destabilizing, the access dimension actually reduces the future occurrence of a crisis. When a financial institution's efficiency has a negative sign, a banking crisis is not significantly affected. Similar results are observed for the indicators of financial market development: a positive sign for the depth and a negative sign for the access dimension. Nevertheless, almost all coefficients are not statistically different from 0 , and thus, the impact of an improvement in financial institution or market efficiency is quite small.

Tables (2)-(4) report the estimates of model (3), where the dependent variable is the systemic banking crisis index explained by indicators of financial development and macrovariables, considering clusters of countries according to their financial market development. ${ }^{8}$ Following Svirydzenka (2016), three clusters have thus been created: one for the least income developed countries (LIDC), one for the emerging markets (EM), and the last one for the advanced markets (AM). We observe that for all of them, financial institution development has a destabilizing impact. Even if the aggregate variables $F D, F I$ and $F M$ are only significant in the case of the advanced countries' cluster, sub-indices are significant for the three clusters. From the analysis of models (4) to (6), it appears that financial institution development is more important for predicting banking crises than financial markets are. This fact highlights the key role played by financial intermediates in the occurrence of banking turmoil. Still, the analysis of Tables (3) to (5) reveal important differences between the three groups of countries. In advanced economies, depth (FID) and access (FIA) are actually destabilizing and increase the probability of a future occurrence of a crisis. This result suggests that regulators in these countries should not only control the amount invested/borrowed or the efficiency of financial institutions, but also have a particular monitoring of the access to financial institutions. In contrast, for LIDC and EM, only the financial institution depth constitutes a leading indicator for future crises. The access to financial institutions increases financial stability and reduces the probability of financial crises a year ahead. Such a result is clearly linked to the problem of financial inclusion. In LIDC/EM countries, inequality in the access to indirect finance constitutes a constraint for the real economy and thus, increases the probability of occurrence of a banking crisis. A difference between the groups appears also with respect to the macro-fundamental variables. We observe that while term spread and output growth are important for the occurrence of future banking crises in advanced economies, only the last term matters in EM. Such a finding could be due to the low level of maturity in the least advanced countries. For LIDC, we do not include the spread term because of data availability, which is not very important as most of these countries are small open economies that are thus interest rate takers with unmature financial capital markets.

\footnotetext{
${ }^{8}$ See Svirydzenka (2016)
} 
Table 1: Estimation Results

\begin{tabular}{|c|c|c|c|c|c|c|}
\hline Model & (1) & $(2)$ & $(3)$ & $(4)$ & (5) & $(6)$ \\
\hline \multirow[t]{2}{*}{ constant } & $-3.122^{* * *}$ & $-3.166^{* * *}$ & $-2.927 * * *$ & $-3.235^{* * *}$ & $-2.970^{* * * *}$ & $-3.197^{* * *}$ \\
\hline & $(0.686)$ & $(0.703)$ & $(0.682)$ & $(0.735)$ & $(0.681)$ & $(0.740)$ \\
\hline \multirow[t]{3}{*}{ lag binary } & $3.880^{* * *}$ & $3.904^{* * *}$ & $3.856^{* * *}$ & $3.840^{* * *}$ & $3.843^{* * *}$ & $3.815^{* * *}$ \\
\hline & $(0.170)$ & $(0.170)$ & $(0.170)$ & $(0.171)$ & $(0.170)$ & $(0.172)$ \\
\hline & & & \multicolumn{4}{|c|}{ Financial development variables } \\
\hline$F D_{-1}$ & $\begin{array}{r}2.722^{* * * *} \\
(0.900)\end{array}$ & & & & & \\
\hline$F I_{-1}$ & & $\begin{array}{c}1.755^{*} \\
(1.065)\end{array}$ & & & & \\
\hline$F M_{-1}$ & & & $\begin{array}{r}2.236^{* * * *} \\
(0.662)\end{array}$ & & & \\
\hline$F I D_{-1}$ & & & & $\begin{array}{r}5.690^{* * * *} \\
(1.470)\end{array}$ & & $\begin{array}{r}5.144^{* * * *} \\
(1.861)\end{array}$ \\
\hline \multirow[t]{2}{*}{$F I A_{-1}$} & & & & $-2.700 * * *$ & & $-2.784^{* * *}$ \\
\hline & & & & (1.309) & & $(1.366)$ \\
\hline \multirow[t]{2}{*}{$F I E_{-1}$} & & & & -1.370 & & -0.239 \\
\hline & & & & $(0.889)$ & & $(0.884)$ \\
\hline \multirow[t]{2}{*}{$F M D_{-1}$} & & & & & $2.260 * * *$ & 1.482 \\
\hline & & & & & $(0.954)$ & $(1.045)$ \\
\hline \multirow[t]{2}{*}{$F M A_{-1}$} & & & & & -1.450 & $-1.911^{*}$ \\
\hline & & & & & $(1.010)$ & $(1.106)$ \\
\hline \multirow[t]{3}{*}{$F M E_{-1}$} & & & & & 0.704 & 0.836 \\
\hline & & & & & $(0.557)$ & $(0.565)$ \\
\hline & \multicolumn{6}{|c|}{ Macro-control variables } \\
\hline \multirow[t]{2}{*}{ Spread } & $-0.062^{*}$ & -0.0501 & $-0.066^{* *}$ & $-0.069^{* *}$ & $-0.069^{* *}$ & $-0.075^{* * *}$ \\
\hline & $(0.025)$ & $(0.034)$ & $(0.035)$ & $(0.037)$ & $(0.036)$ & $(0.038)$ \\
\hline \multirow[t]{2}{*}{ Output growth } & $-0.101^{* * *}$ & $-0.099^{* * *}$ & $-0.123^{* * *}$ & $-0.100 * * *$ & $-0.106^{* * *}$ & $-0.105^{* * *}$ \\
\hline & $(0.019)$ & $(0.184)$ & $(0.018)$ & $(0.018)$ & $(0.019)$ & $(0.019)$ \\
\hline
\end{tabular}

Notes: This table reports the estimates obtained from the dynamic logit models (1) to (6) for the panel of 98 countries from $1980-2016$. Standard errors are reported within brackets below the estimates. ***,** and * report significance at $99 \%, 95 \%$ and $90 \%$. 
Table 2: Estimation Results - Advanced Economies

\begin{tabular}{|c|c|c|c|c|c|c|}
\hline Model & (1) & $(2)$ & $(3)$ & (4) & $(5)$ & (6) \\
\hline \multirow[t]{2}{*}{ constant } & $-7.471^{* * * *}$ & $-10.408^{* * *}$ & $-5.533^{* * *}$ & $-8.381^{* * *}$ & $-5.358^{* * *}$ & $-6.222^{* *}$ \\
\hline & (1.399) & (2.173) & (1.062) & (2.217) & (1.061) & (2.471) \\
\hline \multirow[t]{3}{*}{ lag binary } & $4.315^{* * *}$ & $4.428^{* * *}$ & $4.290^{* * *}$ & $4.257^{* * * *}$ & $4.268^{* * *}$ & $4.156^{* * *}$ \\
\hline & $(0.364)$ & $(0.368)$ & $(0.360)$ & $(0.374)$ & $(0.360)$ & $(0.377)$ \\
\hline & & \multicolumn{5}{|c|}{ Financial development variables } \\
\hline$F D_{-1}$ & $\begin{array}{r}6.279^{* * * *} \\
(1.444)\end{array}$ & & & & & \\
\hline$F I_{-1}$ & & $\begin{array}{r}9.849^{* * * *} \\
(2.503)\end{array}$ & & & & \\
\hline$F M_{-1}$ & & & $\begin{array}{r}3.952^{* * *} * \\
(0.941)\end{array}$ & & & \\
\hline$F I D_{-1}$ & & & & $\begin{array}{r}6.660^{* * *} * \\
(2.146)\end{array}$ & & $\begin{array}{r}2.363 \\
(3.127)\end{array}$ \\
\hline$F I A_{-1}$ & & & & $\begin{array}{r}5.892^{* * * *} \\
(2.286)\end{array}$ & & $\begin{array}{r}6.226^{* *} \\
(2.586)\end{array}$ \\
\hline$F I E_{-1}$ & & & & $\begin{array}{r}-9.114^{* *} \\
(3.710)\end{array}$ & & $\begin{array}{r}-11.972^{* * *} \\
(4.065)\end{array}$ \\
\hline$F M D_{-1}$ & & & & & $\begin{array}{r}2.958^{* * *} \\
(1.473)\end{array}$ & $\begin{array}{c}3.063^{*} \\
(1.717)\end{array}$ \\
\hline$F M A_{-1}$ & & & & & $\begin{array}{r}-0.437 \\
(1.527)\end{array}$ & $\begin{array}{r}-1.162 \\
(1.752)\end{array}$ \\
\hline$F M E_{-1}$ & & & & & $\begin{array}{r}0.790 \\
(0.987)\end{array}$ & $\begin{array}{r}0.545 \\
(1.051)\end{array}$ \\
\hline & & & Macro-cor & rol variable & & \\
\hline Spread & $\begin{array}{r}-0.109 \\
(0.068)\end{array}$ & $\begin{array}{r}-0.099 \\
(0.069)\end{array}$ & $\begin{array}{r}-0.101 \\
(0.066)\end{array}$ & $\begin{array}{c}-0.148^{*} \\
(0.082)\end{array}$ & $\begin{array}{c}-0.118^{*} \\
(0.070)\end{array}$ & $\begin{array}{r}-0.184^{* * *} \\
(0.082)\end{array}$ \\
\hline Output growth & $\begin{array}{r}-0.149^{* *} \\
(0.070)\end{array}$ & $\begin{array}{c}-0.131^{*} \\
(0.070)\end{array}$ & $\begin{array}{r}-0.156^{* *} \\
(0.070)\end{array}$ & $\begin{array}{r}-0.109 \\
(0.073)\end{array}$ & $\begin{array}{r}-0.173^{* *} \\
(0.072)\end{array}$ & $\begin{array}{r}-0.149^{* *} \\
(0.075)\end{array}$ \\
\hline
\end{tabular}

Notes: This table reports the estimates obtained from the dynamic logit models (1) to (6) for the panel of 23 countries from $1980-2016$. Standard errors are reported within brackets below the estimates. ***, ** and * report significance at $99 \%, 95 \%$ and $90 \%$. 
Table 3: Estimation Results - Emerging Markets

\begin{tabular}{|c|c|c|c|c|c|c|}
\hline Model & (1) & $(2)$ & $(3)$ & (4) & (5) & $(6)$ \\
\hline \multirow[t]{2}{*}{ constant } & $-2.386 * * *$ & $-2.256^{* * *}$ & $-2.696^{* * *}$ & $-2.367 * * *$ & $-2.763^{* * *}$ & $-2.791^{* * *}$ \\
\hline & $(0.690)$ & $(0.764)$ & $(0.622)$ & $(0.884)$ & $(0.653)$ & $(0.923)$ \\
\hline \multirow[t]{3}{*}{ lag binary } & $3.597^{* * *}$ & $3.590^{* * *}$ & $3.621^{* * *}$ & $3.579^{* * * k}$ & $3.548^{* * * *}$ & $3.527^{* * *}$ \\
\hline & $(0.257)$ & $(0.258)$ & $(0.257)$ & $(0.265)$ & $(0.260)$ & $(0.268)$ \\
\hline & & & \multicolumn{4}{|c|}{ Financial development variables } \\
\hline$F D_{-1}$ & $\begin{array}{r}-2.223 \\
(1.454)\end{array}$ & & & & & \\
\hline$F I_{-1}$ & & $\begin{array}{r}-1.861 \\
(1.369)\end{array}$ & & & & \\
\hline$F M_{-1}$ & & & $\begin{array}{r}-1.693 \\
(1.261)\end{array}$ & & & \\
\hline$F I D_{-1}$ & & & & $\begin{array}{r}8.422^{* * * *} \\
(2.969)\end{array}$ & & $\begin{array}{r}11.339 * * * \\
(3.302)\end{array}$ \\
\hline \multirow[t]{2}{*}{$F I A_{-1}$} & & & & $-10.139^{* * *}$ & & $-9.247^{* * * *}$ \\
\hline & & & & $(2.621)$ & & $(2.666)$ \\
\hline \multirow[t]{2}{*}{$F I E_{-1}$} & & & & $2.334^{*}$ & & $2.338^{*}$ \\
\hline & & & & $(1.239)$ & & $(1.229)$ \\
\hline \multirow[t]{2}{*}{$F M D_{-1}$} & & & & & -1.020 & -1.549 \\
\hline & & & & & $(1.925)$ & $(2.109)$ \\
\hline \multirow[t]{2}{*}{$F M A_{-1}$} & & & & & -2.818 & $-3.402^{*}$ \\
\hline & & & & & $(1.727)$ & $(1.964)$ \\
\hline \multirow[t]{3}{*}{$F M E_{-1}$} & & & & & 0.866 & 0.899 \\
\hline & & & & & $(0.755)$ & $(0.784)$ \\
\hline & \multicolumn{6}{|c|}{ Macro-control variables } \\
\hline \multirow[t]{2}{*}{ Spread } & -0.027 & -0.036 & -0.023 & -0.048 & -0.023 & -0.030 \\
\hline & $(0.050)$ & $(0.049)$ & $(0.050)$ & $(0.053)$ & $(0.053)$ & $(0.056)$ \\
\hline \multirow[t]{2}{*}{ Output growth } & $-0.077^{* * *}$ & $-0.079^{* * *}$ & $-0.076^{* * *}$ & $-0.082^{* * *}$ & $-0.079^{* * *}$ & $-0.081^{* * *}$ \\
\hline & $(0.023)$ & $(0.023)$ & $(0.023)$ & $(0.024)$ & $(0.023)$ & $(0.024)$ \\
\hline
\end{tabular}

Notes: This table reports the estimates obtained from the dynamic logit models (1) to (6) for the panel of 46 countries from $1980-2016$. Standard errors are reported within brackets below the estimates. ***, ** and * report significance at $99 \%$, $95 \%$ and $90 \%$. 
Table 4: Estimation Results - Low-Income Countries

\begin{tabular}{|c|c|c|c|c|c|c|}
\hline Model & $(1)$ & $(2)$ & $(3)$ & (4) & (5) & (6) \\
\hline \multirow[t]{2}{*}{ constant } & $-2.349^{* * *}$ & $-2.443^{* * *}$ & $-2.644^{* * *}$ & -1.479 & $-2.613^{* * *}$ & -1.439 \\
\hline & $(0.905)$ & $(0.903)$ & $(0.698)$ & $(1.035)$ & $(0.700)$ & $(1.064)$ \\
\hline \multirow{3}{*}{ lag binary } & $3.581^{* * *}$ & $3.583^{* * * *}$ & $3.606^{* * * *}$ & $3.347^{* * * *}$ & $3.578^{* * *}$ & $3.331^{* * *}$ \\
\hline & $(0.314)$ & $(0.315)$ & $(0.314)$ & $(0.319)$ & $(0.315)$ & $(0.322)$ \\
\hline & & \multicolumn{5}{|c|}{ Financial development variables } \\
\hline$F D_{-1}$ & $\begin{array}{r}-5.216 \\
(7.581)\end{array}$ & & & & & \\
\hline$F I_{-1}$ & & $\begin{array}{r}-2.292 \\
(4.232)\end{array}$ & & & & \\
\hline$F M_{-1}$ & & & $\begin{array}{r}-7.839 \\
(12.625)\end{array}$ & & & \\
\hline$F I D_{-1}$ & & & & $\begin{array}{r}7.953 \\
(6.545)\end{array}$ & & $\begin{array}{r}8.289 \\
(7.112)\end{array}$ \\
\hline$F I A_{-1}$ & & & & $\begin{array}{r}-66.472^{* * *} \\
(26.328)\end{array}$ & & $\begin{array}{r}-64.489^{* * *} \\
(26.065)\end{array}$ \\
\hline$F I E_{-1}$ & & & & $\begin{array}{r}2.008 \\
(1.625)\end{array}$ & & $\begin{array}{r}1.873^{*} \\
(1.641)\end{array}$ \\
\hline$F M D_{-1}$ & & & & & $\begin{array}{r}-0.804 \\
(5.377)\end{array}$ & $\begin{array}{r}0.047 \\
(6.762)\end{array}$ \\
\hline$F M A_{-1}$ & & & & & -42.402 & -24.078 \\
\hline & & & & & (123.610) & (147.837) \\
\hline$F M E_{-1}$ & & & & & $\begin{array}{r}-19.683 \\
(19.790)\end{array}$ & $\begin{array}{r}-19.087 \\
(22.410)\end{array}$ \\
\hline & & & Macro-con & rol variable & & \\
\hline Model & $(1)$ & $(2)$ & $(3)$ & $(4)$ & $(5)$ & (6) \\
\hline Output growth & $\begin{array}{r}-0.112^{* * * *} \\
(0.028)\end{array}$ & $\begin{array}{r}-0.112^{* * * *} \\
(0.028)\end{array}$ & $\begin{array}{r}-0.111^{* * * *} \\
(0.028)\end{array}$ & $\begin{array}{r}-0.101^{* * * *} \\
(0.028)\end{array}$ & $\begin{array}{r}-0.107^{* * * *} \\
(0.028)\end{array}$ & $\begin{array}{r}-0.099^{* * * *} \\
(0.028)\end{array}$ \\
\hline
\end{tabular}

Notes: This table reports the estimates obtained from the dynamic logit models (1) to (6) for the panel of 29 countries from 1980 - 2016. Because of data availability, the term spread is not included for this group of countries. Standard errors are reported within brackets below the 


\section{ROBUSTNESS CHECKS}

To assess our results, several robustness checks are proposed:

In the first three robustness checks, we consider a nonlinear model for which financial development interacts with the regimes of the nonperforming loans $(N P L)$ and the capital account openness ( $K A O$, measured here by the method of Chinn and Ito, 2006). These variables $z_{j}$, with $j=1, \ldots, 3$, are included in the model via an index $\mathbb{1}_{z}$, which takes the value of 1 for a particular year $t$ and a particular country $i$ if $z_{i, t}>$ median $\left(z_{i}\right)$ and 0 otherwise. Model(1) takes the following form:

$\operatorname{Pr}\left(y_{i t}=1\right)=F\left(\alpha \cdot y_{i, t-1}+x_{i, t-1} \beta+\delta \pi_{i, t-1}+\gamma \cdot x_{i, t-1} \cdot \mathbb{1}\left(z_{j, i, t-1}\right)+\eta_{i}\right)$

A $\gamma$ associated with $z_{N P L}$ that is positive and significantly different from 0 indicates that ahighamount of netperforming loans would amplify banking instability brought by financial development. Similarly, a positive coefficient for the interactive term $z_{K A O}$ suggests that the more open the capital account of a country is, the more destabilizing financial development is. Wealso consider the exchange rate regime (Err) measured via the method of Levy-Yeyati and Sturzenegger (2005), (2016). A dummy is then simultaneously introduced for fixed and flexible exchange rate regimes. ${ }^{9}$

Table (5) reports the results obtained for the previous robustness checks. It turns out that the introduction of interactive terms (KAO and $N P L)$ does not affect the relationship between financial development and the banking crisis, as none of the coefficients associated with the interaction term are significantly different from zero at $99 \%$. This result thus signifies that our previous findings hold whatever the degree of capital openness or the amount of nonperforming loans. Similar results are obtained for fixed exchange rates (third panel of Table 5). In contrast, it appears that the flexible exchange rate regime affects the previous results. Indeed, in this exchange rate regime, access to financial institutions becomes destabilizing, whereas financial deepening is stabilizing. This finding can be explained by capital movement on the foreign exchange markets. In this case, only the efficiency of financial institutions appears to decrease the occurrence of a banking crisis.

The model is re-estimated for the period before 2008 in order to check if the great crisis has structurally modified the relationship between finance and the crises. The results of the estimations are reported in Table (6) and do not show a major quantitative difference from those reported in Table (1). This observation thus signifies that the impact of financial development on future banking crises is not driven by the great crisis and is quite stable over time.

So far, models have been estimated for a one-lag horizon. In other words, the previous results show how financial development is improving or deteriorating the probability of occurrence of a banking crisis in the coming year. This last robustness check explores this relationship for a horizon of two years and considers hence the following model: $\operatorname{Pr}\left(y_{i t}=1\right)=F\left(\eta_{i}+\alpha y_{i, t-2}+x_{i, t-2} \beta+\delta \pi_{i, t-2}\right)$. The results of the estimations are reported in Table

\footnotetext{
${ }^{9}$ The sum of the dummy variables for fixed and flexible exchangerates does not amount to one as it exists in some cases of undefined or intermediate exchange rate regimes.
} 
(7). Again, the results obtained are similar to those reported in Table (1). These findings, as well as the previous one (for the pre-crisis period), support the idea that the link obtained between financial development and the probability of a banking crisis is structural: this holds whatever the sample and the horizon considered. This outcome clearly calls for structural regulation policies, which should be independent of the business cycle or a specific temporary event. 
Table 5: Estimation Results - Kaopen - NPL - Exchange Rate

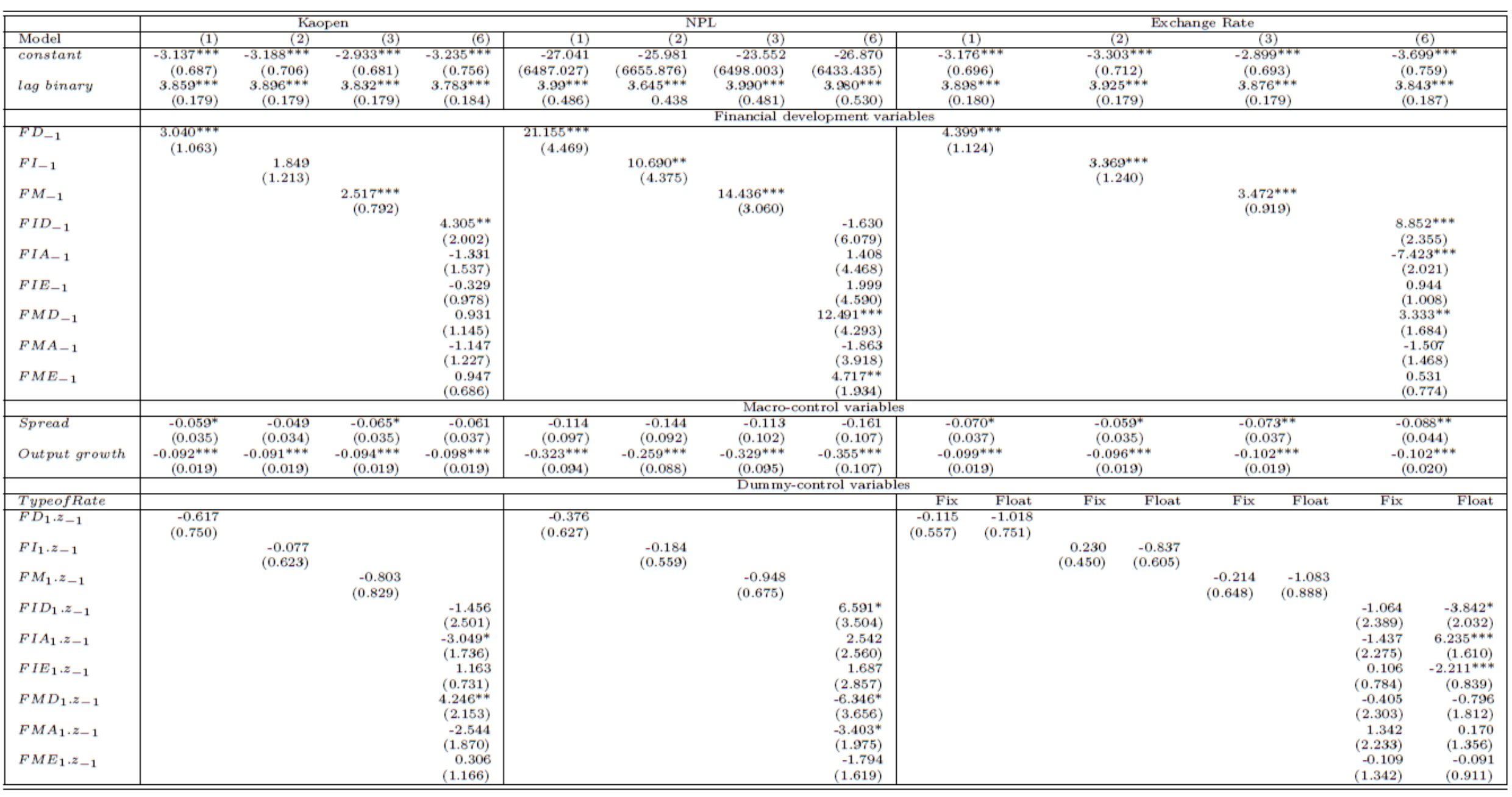

Notes: This table reports the estimates obtained from the dynamic logit models (1), (2), (3), and (6) for the panel of: 88 countries from 1980 - 2016 - Kaopen, 61 countries from 2001 - 2016 - NPL, 93 countries from 1980 - 2013 - Exchange Rate. Standard errors are reported within brackets below the estimates. ***, ** and * report significance at $99 \%, 95 \%$ and $90 \%$. 
Table 6: Estimation Results $1980-2008$

\begin{tabular}{|c|c|c|c|c|c|c|}
\hline Model & $(1)$ & $(2)$ & $(3)$ & $(4)$ & $(5)$ & $(6)$ \\
\hline \multirow[t]{2}{*}{ constant } & $-2.938^{* * *}$ & $-3.186^{* * *}$ & $-2.652^{* * * *}$ & $-3.433^{* * *}$ & $-2.747 * * *$ & $-3.471^{* * * *}$ \\
\hline & $(0.674)$ & $(0.695)$ & $(0.667)$ & $(0.726)$ & $(0.669)$ & $(0.733)$ \\
\hline \multirow[t]{3}{*}{ lag binary } & $3.437^{* * * *}$ & $3.415^{* * * *}$ & $3.420^{* * * *}$ & $3.408^{* * * *}$ & $3.437^{* * * *}$ & $3.416^{\text {**** }}$ \\
\hline & $(0.195)$ & $(0.195)$ & $(0.194)$ & $(0.197)$ & $(0.195)$ & $(0.198)$ \\
\hline & & \multicolumn{5}{|c|}{ Financial development variables } \\
\hline$F D_{-1}$ & $\begin{array}{r}4.131^{* * * *} \\
(1.086)\end{array}$ & & & & & \\
\hline$F I_{-1}$ & & $\begin{array}{r}4.132^{* * * *} \\
(1.341)\end{array}$ & & & & \\
\hline$F M_{-1}$ & & & $\begin{array}{r}2.730^{* * * * *} \\
(0.761)\end{array}$ & & & \\
\hline$F I D_{-1}$ & & & & $\begin{array}{r}9.694^{* * * *} \\
(2.077)\end{array}$ & & $\begin{array}{r}9.234^{* * * *} \\
(2.342)\end{array}$ \\
\hline$F I A_{-1}$ & & & & $\begin{array}{r}-4.337^{* *} \\
(2.209)\end{array}$ & & $\begin{array}{r}-3.652 \\
(2.248)\end{array}$ \\
\hline$F I E_{-1}$ & & & & $\begin{array}{r}0.348 \\
(0.929)\end{array}$ & & $\begin{array}{r}0.244 \\
(0.924)\end{array}$ \\
\hline$F M D_{-1}$ & & & & & $\begin{array}{r}3.423^{* * *} \\
(1.142)\end{array}$ & $\begin{array}{l}2.217^{*} \\
(1.250)\end{array}$ \\
\hline$F M A_{-1}$ & & & & & $\begin{array}{l}-1.274 \\
(1.122)\end{array}$ & $\begin{array}{l}-2.538^{*} \\
(1.304)\end{array}$ \\
\hline$F M E_{-1}$ & & & & & $\begin{array}{r}0.047 \\
(0.643)\end{array}$ & $\begin{array}{c}-0.063 \\
(0.666)\end{array}$ \\
\hline & & & Macro-con & rol variable & & \\
\hline Spread & $\begin{array}{r}-0.100^{* * *} \\
(0.044)\end{array}$ & $\begin{array}{r}-0.085^{* *} \\
(0.043)\end{array}$ & $\begin{array}{r}-0.102^{* *} \\
(0.044)\end{array}$ & $\begin{array}{r}-0.110^{* *} \\
(0.053)\end{array}$ & $\begin{array}{r}-0.107^{* * *} \\
(0.046)\end{array}$ & $\begin{array}{r}-0.112^{* *} \\
(0.054)\end{array}$ \\
\hline Output growth & $\begin{array}{r}-0.090^{* * * *} \\
(0.019) \\
\end{array}$ & $\begin{array}{r}-0.084^{* * * *} \\
(0.018) \\
\end{array}$ & $\begin{array}{r}-0.092^{* * * *} \\
(0.019) \\
\end{array}$ & $\begin{array}{r}-0.089^{* * *} \\
(0.019) \\
\end{array}$ & $\begin{array}{r}-0.095^{* * * *} \\
(0.019) \\
\end{array}$ & $\begin{array}{r}-0.093^{* * * *} \\
(0.019) \\
\end{array}$ \\
\hline
\end{tabular}

Notes: This table reports the estimates obtained from the dynamic logit models (1) to (6) for the panel of 98 countries from $1980-2008$. Standard errors are reported within brackets below the estimates. ***,** and * report significance at $99 \%, 95 \%$ and $90 \%$. 
Table 7: Estimation Results with two lags 1980 - 2016

\begin{tabular}{|c|c|c|c|c|c|c|}
\hline Model & $(1)$ & $(2)$ & $(3)$ & $(4)$ & $(5)$ & $(6)$ \\
\hline \multirow[t]{2}{*}{ constant } & $-2.517 * * *$ & $-2.608^{* * * *}$ & $-2.293^{* * *}$ & $-2.741^{* * *}$ & $-2.352^{* * * *}$ & $-2.683^{* * * *}$ \\
\hline & $(0.573)$ & $(0.585)$ & $(0.571)$ & $(0.613)$ & $(0.571)$ & $(0.618)$ \\
\hline \multirow[t]{3}{*}{ lag binary } & $2.165^{* * *}$ & $2.214^{* * *}$ & $2.134^{* * * *}$ & $2.107^{* * *}$ & $2.113^{* * *}$ & $2.069^{* * *}$ \\
\hline & $(0.146)$ & $(0.145)$ & $(0.147)$ & $(0.171)$ & $(0.147)$ & $(0.149)$ \\
\hline & & \multicolumn{5}{|c|}{ Financial development variables } \\
\hline$F D_{-2}$ & $\begin{array}{r}3.137^{* * * *} \\
(0.719)\end{array}$ & & & & & \\
\hline$F I_{-2}$ & & $\begin{array}{r}2.261^{* * * *} \\
(0.855)\end{array}$ & & & & \\
\hline$F M_{-2}$ & & & $\begin{array}{r}2.502^{* * * *} \\
(0.531)\end{array}$ & & & \\
\hline$F I D_{-2}$ & & & & $\begin{array}{r}6.903^{* * * *} \\
(2.128)\end{array}$ & & $\begin{array}{r}5.953^{* * *} \\
(1.524)\end{array}$ \\
\hline$F I A_{-2}$ & & & & $\begin{array}{r}-3.184^{* * * *} \\
(1.079)\end{array}$ & & $\begin{array}{r}-3.254^{* * * *} \\
(1.122)\end{array}$ \\
\hline$F I E_{-2}$ & & & & $\begin{array}{r}-0.053 \\
(0.713)\end{array}$ & & $\begin{array}{r}-0.132 \\
(0.708)\end{array}$ \\
\hline$F M D_{-2}$ & & & & & $\begin{array}{r}2.708^{* * * *} \\
(0.763)\end{array}$ & $\begin{array}{r}1.849^{* *} \\
(0.834)\end{array}$ \\
\hline$F M A_{-2}$ & & & & & $\begin{array}{r}-1.285 \\
(0.801)\end{array}$ & $\begin{array}{r}-1.771^{* *} \\
(0.890)\end{array}$ \\
\hline$F M E_{-2}$ & & & & & $\begin{array}{r}0.403 \\
(0.450)\end{array}$ & $\begin{array}{r}0.484 \\
(0.456)\end{array}$ \\
\hline & & & Macro-con & rol variable & & \\
\hline Spread & $\begin{array}{r}-0.068^{* *} \\
(0.030)\end{array}$ & $\begin{array}{c}-0.055^{*} \\
(0.029)\end{array}$ & $\begin{array}{r}-0.072^{* *} \\
(0.031)\end{array}$ & $\begin{array}{r}-0.080^{* *} \\
(0.037)\end{array}$ & $\begin{array}{r}-0.078^{* *} \\
(0.032)\end{array}$ & $\begin{array}{r}-0.088^{* *} \\
(0.036)\end{array}$ \\
\hline Output growth & $\begin{array}{r}-0.096^{* * * *} \\
(0.016)\end{array}$ & $\begin{array}{r}-0.093^{* * * *} \\
(0.016)\end{array}$ & $\begin{array}{r}-0.099^{* * * *} \\
(0.016)\end{array}$ & $\begin{array}{r}-0.093^{* * * *} \\
(0.016)\end{array}$ & $\begin{array}{r}-0.101^{* * * *} \\
(0.016)\end{array}$ & $\begin{array}{r}-0.098^{* * *} \\
(0.016)\end{array}$ \\
\hline
\end{tabular}

Notes: This table reports the estimates obtained from the dynamic logit models (1) to (6) for the panel of 98 countries from $1980-2016$. Standard errors are reported within brackets below the estimates. ***,** and * report significance at $99 \%, 95 \%$ and $90 \%$. 


\section{CONCLUSION AND POLICY IMPLICATIONS}

This paper assesses whether and how financial development triggers the occurrence of banking crises. This question clearly fits the literature evaluating whether more finance is always good for growth and financial stability. The innovation of the paper is twofold: First, it considers a database, decomposing financial development into its main components, i.e., access, depth and efficiency, and covering most of the world's economies (98 countries). Second, this study relies on a dynamic logit panel model, which includes past crisis observations in order to obtain unbiased estimators as well as a fixed effect to address unobserved heterogeneity. It appears that financial development, from an institutional dimension and to a lesser extent a market dimension, increases the probability of occurrence of a crisis within a one- to two-year horizon. The explosion of the fintech industry (mobile payment, cryptocurrency, and offshore banking, to quote a few) is a matter of concern for regulators and supervisors, who should adjust their macroprudential rules accordingly. Going deeper, the paper indicates that the destabilizing dimension of financial development is different in advanced and emerging/low income countries. For advanced countries, we observe that financial access and depth are destabilizing, whereas efficiency reduced the future occurrence of a banking crisis. In contrast, for emerging countries, financial access is stabilizing, and depth/efficiency is not. We thus observe that the impact of financial development on stability is not homogeneous; rather, it varies with its component and the country under consideration. These findings have important consequences for macroprudential policies. First, financial stability assessments (such as the Financial Sector Assessment Program, FSAP, jointly conducted by the IMF and the World Bank) should include a shock associated with financial development (as well as with each of these components: access, depth and efficiency). By doing so, the financial sector's vulnerabilities would be better assessed, particularly in front of the surge of financial innovations. Second, financial regulation (in particular, the Basel agreements for the banking sector) should take into account the specificities of emerging markets compared to advanced countries. For example, higher capital requirements should be imposed on banks in advanced economies to smooth the increase in financial access and depth, whereas this should not be the case for emerging markets' financial institutions. Similarly, regulators should encourage higher efficiencies in the financial institutions. 


\section{REFERENCES}

Aghion, Philippe, Peter Howitt, and David Mayer-Foulkes. "The effect of financial development on convergence: Theory and evidence." The Quarterly Journal of Economics 120.1 (2005): 173-222.

Arcand, Jean Louis, Enrico Berkes, and Ugo Panizza. "Too much finance?" Journal of Economic Growth 20.2 (2015): 105-148.

Barrell, Ray, et al. "How idiosyncratic are banking crises in OECD countries?" National Institute Economic Review 216.1 (2011): R53-R58.

Beck, Thorsten, and Samuel Munzele Maimbo, eds. Financial sector development in Africa: Opportunities and challenges. The World Bank, 2012.

Bencivenga, Valerie R., and Bruce D. Smith. "Financial intermediation and endogenous growth." The review of economic studies 58.2 (1991): 195-209.

Bernanke, Ben S. Blinder, Alan S., 1988. "Credit, money, and aggregate demand." The American economic review, 78.2 (1988): 435-439.

Borio, Claudio EV, and Philip William Lowe. "Asset prices, financial and monetary stability: exploring the nexus." (2002).

Borio, Claudio, and Mathias Drehmann. "Towards an operational framework for financial stability: 'fuzzy' measurement and its consequences." (2009).

Bordo, MichaelD., and Christopher M. Meissner. "Does inequality lead to a financial crisis?" Journal of International Money and Finance 31.8 (2012): 2147-2161.

Bunda, Irina, and Michele Ca'Zorzi. "Signals from housing and lending booms." Emerging Markets Review 11.1 (2010): 1-20.

Buyukkarabacak, Berrak, and Neven T. Valev. "The role of household and business credit in banking crises." Journal of Banking \& Finance 34.6 (2010): 1247-1256.

Candelon, Bertrand, Elena-Ivona Dumitrescu, Christophe Hurlin and Franz C. Palm. "Modeling Financial Crisis Mutation" in Advances in Econometrics Vol. 31 in honor of Chris Sims "VAR Models in Macroeconomics, Financial Econometrics, and Forecasting," (2013): 395419.

Candelon, Bertrand, Elena-Ivona Dumitrescu, and Christophe Hurlin. "Currency crisis early warning systems: Why they should be dynamic." International Journal of Forecasting 30.4 (2014): 1016-1029.

Candelon, Bertrand, Alina Carare, and Jean-Baptiste Hasse. "Globalization and the New Normal." (2018). 
Carro, Jesus M. "Estimating dynamic panel data discrete choice models with fixed effects." Journal of Econometrics 140.2 (2007): 503-528.

Cecchetti, Stephen G., and Enisse Kharroubi. "Reassessing the impact of finance on growth." (2012).

Chinn, Menzie D., and Hiro Ito. "What matters for financial development? Capital controls, institutions, and interactions." Journal of development economics 81.1 (2006): 163-192.

Cihak, Martin. "Systemic loss: A measure of financial stability." Czech Journal of Economics and Finance 57.1-2 (2007): 5-26.

Davis, E. Philip, and Dilruba Karim. "Comparing early warning systems for banking crises." Journal of Financial stability 4.2 (2008): 89-120.

Davis, E. Philip, and Dilruba Karim. "Could early warning systems have helped to predict the sub-prime crisis?" National Institute Economic Review 206.1 (2008): 35-47.

Davis, E. Philip, Dilruba Karim, and Iana Liadze. "Should multivariate early warning systems for banking crises pool across regions?" Review of World Economics 147.4 (2011): 693716.

Dell'Ariccia, Giovanni, and Robert Marquez. "Information and bank credit allocation." Journal of Financial Economics 72.1 (2004): 185-214.

Demirguc-Kunt, Asli, and Enrica Detragiache. "The determinants of banking crises in developing and developed countries." Staff Papers 45.1 (1998): 81-109.

Demirguc-Kunt, Asli, and Enrica Detragiache. Monitoring banking sector fragility: a multivariate logit approach. The World BankEconomic Review 14.2 (2000): 287-307.

Demirguc-Kunt, Asli, and Enrica Detragiache. "Does deposit insurance increase banking system stability? An empirical investigation." Journal of monetary economics 49.7 (2002): 1373-1406.

Demirguc-Kunt, Asli, and Enrica Detragiache. Cross-country empirical studies of systemic bank distress: a survey. The World Bank, 2005.

Demirguc-Kunt, Asli, María Soledad, and Martínez Pería. A framework for analyzing competition in the banking sector: an application to the case of Jordan. The World Bank, 2010.

Drehmann, Mathias, Claudio EV Borio, and Kostas Tsatsaronis. "Anchoring countercyclical capital buffers: the role of credit aggregates." (2011). 
Drehmann, Mathias, and Mikael Juselius. "Evaluating early warning indicators of banking crises: Satisfying policy requirements." International Journal of Forecasting 30.3 (2014): 759- 780.

Duca, Marco Lo, and Tuomas A. Peltonen. "Assessing systemic risks and predicting systemic events." Journal of Banking \& Finance 37.7 (2013): 2183-2195.

Goldsmith, Raymond William. Financial structure and development. No. HG174G57. 1969.

Greenwood, Jeremy, and Boyan Jovanovic. "Financial development, growth, and the distribution of income." Journal of political Economy 98.5, Part 1 (1990): 1076-1107.

Hahm, Joon-ho, Hyun Song Shin, and Kwanho Shin. "Noncore bank liabilities and financial vulnerability." Journal of Money, Credit and Banking 45.s1 (2013): 3-36.

Jorda, Oscar, Moritz Schularick, and Alan M. Taylor. "Financial crises, credit booms, and external imbalances: 140 years of lessons." IMF Economic Review 59.2 (2011): 340-378.

Kaminsky, Graciela, Saul Lizondo, and Carmen M. Reinhart. "Leading indicators of currency crises." Staff Papers 45.1 (1998): 1-48.

Kaminsky, Graciela L., and Carmen M. Reinhart. "The twin crises: the causes of banking and balance-of-payments problems." American economic review 89.3 (1999): 473-500.

Kauko, Karlo. "How to foresee banking crises? A survey of the empirical literature." Economic Systems 38.3 (2014): 289-308.

Kauppi, Heikki, and Pentti Saikkonen. "Predicting U.S. recessions with dynamic binary response models." The Review of Economics and Statistics 90.4 (2008): 777-791.

Keeley, Michael C. "Deposit Insurance, Risk, and Market Power in Banking." American Economic Review, American Economic Association, 80.5 (1990): 1183-1200.

Kiyotaki, Nobuhiro, and John Moore. "Credit cycles." Journal of political economy 105.2 (1997): 211-248.

Laeven, Luc, and Fabian Valencia. "Systemic banking crises database." IMF Economic Review 61.2 (2013): 225-270.

Law, Siong Hook, and Nirvikar Singh. "Does too much finance harm economic growth?" Journal of Banking \& Finance 41 (2014): 36-44.

Levine, Ross. "Finance and growth: theory and evidence." Handbook of economic growth 1 (2005): 865-934. 
Levy-Yeyati, Eduardo, and Federico Sturzenegger. "Classifying exchange rate regimes: Deeds vs. words." European economic review 49.6 (2005): 1603-1635.

Levy-Yeyati, Eduardo, and Federico Sturzenegger. "Classifying exchange rate regimes: 15 years later." (2016).

Lucas Jr., RobertE. "On the mechanics of economic development." Journal of monetary economics 22.1 (1988): 3-42.

Mathonnat, Clement, and Alexandru Minea. "Financial development and the occurrence of banking crises." Journal of Banking \& Finance 96(2018): 344-354.

McKinnon, Ronald, and Edward Shaw. "Financial deepening in economic development." Washington, Brookings Institution (1973).

Minsky, Hyman P. "Stabilizing an Unstable Economy: The Lessons for Industry, Finance and Government." (1986).

Philippon, Thomas. "Financiers versus engineers: Should the financial sector be taxed or subsidized?" American Economic Journal: Macroeconomics 2.3 (2010): 158-82.

Rajan, Raghuram, and Luigi Zingales. "Financial dependence and growth." American Economic Review (1998): 559-586.

Rioja, Felix, and Neven Valev. "Does one size fit all?: a reexamination of the finance and growth relationship." Journal of Development economics 74.2 (2004): 429-447.

Rioja, Felix, and Neven Valev. "Finance and the sources of growth at various stages of economic development." Economic Inquiry 42.1 (2004): 127-140.

Robinson, Joan. "The Generalization of the General Theory, In: the Rate of Interest and Other Essays, London: MacMillan." (1952).

Rose, Andrew K., and Mark M. Spiegel. "Cross-country causes and consequences of the crisis: An update." European Economic Review 55.3 (2011): 309-324.

Rousseau, Peter L., and Paul Wachtel. "Equity markets and growth: cross-country evidence on timing and outcomes, 1980-1995." Journal of Banking \& Finance 24.12 (2000): 1933-1957.

Sahay, Ratna, et al. Rethinking financial deepening: Stability and growth in emerging markets. International Monetary Fund, 2016.

Saint-Paul, Gilles. "Technological choice, financial markets and economic development." European Economic Review 36.4 (1992): 763-781. 
Schularick, Moritz, and Alan M. Taylor. "Credit booms gone bust: Monetary policy, leverage cycles, and financial crises, 1870-2008." American Economic Review 102.2 (2012): 1029-61.

Schumpeter, Joseph A. Theory of economic development. New York: Oxford University Press, 1934.

Shaw, Edward Stone. "Financial deepening in economic development." (1973).

Svirydzenka, Katsiaryna. Introducing a new broad-based index of financial development. International Monetary Fund, 2016.

Von Hagen, Jurgen, and Tai-kuang Ho. "Money market pressure and the determinants of banking crises." Journal of Money, Credit and Banking 39.5 (2007): 1037-1066.

Wachtel, Paul. "The evolution of the finance growth nexus." Comparative Economic Studies 53.3 (2011): 475-488. 


\section{APPENDIX I - FINANCIAL DEVELOPMENT INDICATOR CONSTRUCTION}

Table 8: Variable use for building the Financial Development Index

\begin{tabular}{|c|c|c|}
\hline Category & Indicator & Index \\
\hline \multicolumn{2}{|r|}{ Financial Institutions } & FI \\
\hline Depth & $\begin{array}{l}\text { - Private-sector credit to GDP } \\
\text { - Pension fund assets to GDP } \\
\text { - Mutual fund assets to GDP } \\
\text { - Insurance premiums, life and non-life to GDP }\end{array}$ & FID \\
\hline Access & $\begin{array}{l}\text { - Bank branches per } 100,000 \text { adults } \\
\text { - ATMs per } 100,000 \text { adults }\end{array}$ & FIA \\
\hline Efficiency & $\begin{array}{l}\text { - Net interest margin } \\
\text { - Lending-deposits spread } \\
\text { - Non-interest income to total income } \\
\text { - Overhead costs to total assets } \\
\text { - Return on assets } \\
\text { - Return on equity }\end{array}$ & FIE \\
\hline \multicolumn{2}{|r|}{ Financial Markets } & FM \\
\hline Depth & $\begin{array}{l}\text { - Stock market capitalization to GDP } \\
\text { - Stocks traded to GDP } \\
\text { - International debt securities of government to GDP } \\
\text { - Total debt securities of financial corporations to GDP } \\
\text { - Total debt securities of nonfinancial corporations to GDP }\end{array}$ & FMD \\
\hline Access & $\begin{array}{l}\text { - Percent of market capitalization outside of top } 10 \text { largest companies } \\
\text { - Total number of issuers of debt (domestic and external, nonfinancial } \\
\text { and financial corporations) }\end{array}$ & FMA \\
\hline Efficiency & - Stock market turnover ratio (stocks traded to capitalization) & FMD \\
\hline
\end{tabular}

Sources: Sahay et. al (2015) and Svirydzenka (2016) 


\section{APPENDIX II - DATA DESCRIPTION}

Table 9: Country Data

\begin{tabular}{|c|c|c|c|}
\hline Country & IMF Region & Country Group & Banking Crisis \\
\hline Algeria & Middle East and Central Asia & EM & $1990,1991,1992,1993,1994$ \\
\hline Angola & Africa & EM & \\
\hline Australia & Asia and Pacific & $\mathrm{AM}$ & \\
\hline Austria & Europe & $\mathrm{AM}$ & $2008,2009,2010,2011$ \\
\hline Bahamas, The & Western Hemisphere & $\mathrm{EM}$ & \\
\hline Barbados & Western Hemisphere & EM & \\
\hline Belgium & Europe & $\mathrm{AM}$ & $2008,2009,2010,2011,2012,2013,2014$ \\
\hline Belize & Western Hemisphere & EM & \\
\hline Benin & Africa & LIDC & $1988,1989,1990,1991,1992$ \\
\hline Bolivia & Western Hemisphere & LIDC & 1986,1994 \\
\hline Botswana & Africa & EM & \\
\hline Brazil & Western Hemisphere & EM & $1990,1991,1992,1993,1994,1995,1996,1997,1998$ \\
\hline Burundi & Africa & LIDC & $1994,1995,1996,1997,1998$ \\
\hline Cameroon & Africa & LIDC & $1987,1988,1989,1990,1991,1995,1996,1997$ \\
\hline Canada & Western Hemisphere & $\mathrm{AM}$ & \\
\hline Chad & Africa & LIDC & $1983,1992,1993,1994,1995,1996$ \\
\hline Chile & Western Hemisphere & EM & $1981,1982,1983,1984,1985$ \\
\hline Colombia & Western Hemisphere & EM & $1982,1998,1999,2000$ \\
\hline Congo, Dem. Rep. & Africa & LIDC & $1983,1991,1992,1993,1994,1995,1996,1997,1998$ \\
\hline Congo, Rep. & Africa & LIDC & $1992,1993,1994$ \\
\hline Costa Rica & Western Hemisphere & EM & $1987,1988,1989,1990,1991,1994,1995$ \\
\hline Cote d'Ivoire & Africa & LIDC & $1988,1989,1990,1991,1992$ \\
\hline Denmark & Europe & $\mathrm{AM}$ & $2008,2009,2010,2011,2012,2013,2014$ \\
\hline Dominican Republic & Western Hemisphere & EM & 2003,2004 \\
\hline Ecuador & Western Hemisphere & EM & $1982,1983,1984,1985,1986,1998,1999,2000,2001,2002$ \\
\hline Egypt, Arab Rep. & Middle East and Central Asia & EM & 1980 \\
\hline Finland & Europe & $\mathrm{AM}$ & $1991,1992,1993,1994,1995$ \\
\hline France & Europe & $\mathrm{AM}$ & $2008,2009,2010,2011,2012,2013,2014$ \\
\hline Gabon & Africa & EM & \\
\hline Germany & Europe & $\mathrm{AM}$ & $2008,2009,2010,2011$ \\
\hline Ghana & Africa & LIDC & 1982,1983 \\
\hline Greece & Europe & $\mathrm{AM}$ & $2008,2009,2010,2011,2012,2013,2014$ \\
\hline Guatemala & Western Hemisphere & EM & \\
\hline Guyana & Western Hemisphere & LIDC & 1993 \\
\hline Honduras & Western Hemisphere & LIDC & \\
\hline Hungary & Europe & EM & $1991,1992,1993,1994,1995,2008,2009,2010,2011,2012,2013,2014$ \\
\hline Iceland & Europe & $\mathrm{AM}$ & $2008,2009,2010,2011,2012,2013,2014$ \\
\hline India & Asia and Pacific & EM & 1993 \\
\hline Indonesia & Asia and Pacific & EM & $1997,1998,1999,2000,2001$ \\
\hline Ireland & Europe & $\mathrm{AM}$ & $2008,2009,2010,2011$ \\
\hline Israel & Europe & EM & \\
\hline Italy & Europe & $\mathrm{AM}$ & $2008,2009,2010,2011,2012,2013,2014$ \\
\hline Japan & Asia and Pacific & $\mathrm{AM}$ & $1997,1998,1999,2000,2001$ \\
\hline Kenya & Africa & LIDC & $1985,1992,1993,1994$ \\
\hline
\end{tabular}

\section{CInternational Monetary Fund. Not for Redistribution}


APPENDIX II - DATA DESCRIPTION (CONTINUED)

\begin{tabular}{|c|c|c|c|}
\hline Country & IMF Region & Country Group & Banking Crisis \\
\hline Korea, Rep. & Asia and Pacific & EM & 1997,1998 \\
\hline Kuwait & Middle East and Central Asia & EM & $1982,1983,1984,1985$ \\
\hline Lesotho & Africa & LIDC & \\
\hline Luxembourg & Europe & $\mathrm{AM}$ & $2008,2009,2010,2011$ \\
\hline Madagascar & Africa & LIDC & 1988 \\
\hline Malawi & Africa & LIDC & \\
\hline Malaysia & Asia and Pacific & EM & $1997,1998,1999$ \\
\hline Mali & Africa & LIDC & $1987,1988,1989,1990,1991$ \\
\hline Mauritius & Africa & EM & \\
\hline Mexico & Western Hemisphere & EM & $1981,1982,1983,1984,1985,1994,1995,1996$ \\
\hline Morocco & Middle East and Central Asia & EM & $1980,1981,1982,1983,1984$ \\
\hline Nepal & Asia and Pacific & LIDC & 1988 \\
\hline Netherlands & Europe & $\mathrm{AM}$ & $2008,2009,2010,2011,2012,2013,2014$ \\
\hline New Zealand & Asia and Pacific & $\mathrm{AM}$ & \\
\hline Nicaragua & Western Hemisphere & LIDC & $1990,1991,1992,1993,2000,2001$ \\
\hline Niger & Africa & LIDC & $1983,1984,1985$ \\
\hline Norway & Europe & $\mathrm{AM}$ & $1991,1992,1993$ \\
\hline Oman & Middle East and Central Asia & EM & \\
\hline Pakistan & Asia and Pacific & EM & \\
\hline Panama & Western Hemisphere & EM & 1988,1989 \\
\hline Papua New Guinea & Asia and Pacific & LIDC & \\
\hline Paraguay & Western Hemisphere & EM & 1995 \\
\hline Peru & Western Hemisphere & EM & 1983 \\
\hline Philippines & Asia and Pacific & EM & $1983,1984,1985,1986,1997,1998,1999,2000,2001$ \\
\hline Poland & Europe & EM & $1992,1993,1994$ \\
\hline Portugal & Europe & $\mathrm{AM}$ & $2008,2009,2010,2011,2012,2013,2014$ \\
\hline Romania & Europe & EM & $1990,1991,1992$ \\
\hline Rwanda & Africa & LIDC & \\
\hline Senegal & Africa & LIDC & $1988,1989,1990,1991$ \\
\hline Seychelles & Africa & EM & \\
\hline Sierra Leone & Africa & LIDC & $1990,1991,1992,1993,1994$ \\
\hline Singapore & Asia and Pacific & EM & \\
\hline South Africa & Africa & EM & \\
\hline Spain & Europe & $\mathrm{AM}$ & $1980,1981,2008,2009,2010,2011,2012,2013,2014$ \\
\hline Sri Lanka & Asia and Pacific & EM & $1989,1990,1991$ \\
\hline St. Vincent and the Grenadines & Western Hemisphere & LIDC & \\
\hline Sudan & Africa & LIDC & \\
\hline Sweden & Europe & $\mathrm{AM}$ & $1991,1992,1993,1994,1995,2008,2009,2010,2011$ \\
\hline Switzerland & Europe & $\mathrm{AM}$ & $2008,2009,2010,2011$ \\
\hline Thailand & Asia and Pacific & EM & $1983,1997,1998,1999,2000$ \\
\hline Togo & Africa & LIDC & 1993,1994 \\
\hline Trinidad and Tobago & Western Hemisphere & EM & \\
\hline Tunisia & Middle East and Central Asia & EM & 1991 \\
\hline Turkey & Europe & EM & $1982,1983,1984,2000,2001$ \\
\hline United Kingdom & Europe & $\mathrm{AM}$ & $2007,2008,2009,2010,2011,2012,2013,2014$ \\
\hline United States & Western Hemisphere & $\mathrm{AM}$ & $1988,2007,2008,2009,2010,2011$ \\
\hline Uruguay & Western Hemisphere & EM & $1981,1982,1983,1984,1985,2002,2003,2004,2005$ \\
\hline Venezuela, RB & Western Hemisphere & EM & $1994,1995,1996,1997,1998$ \\
\hline Zambia & Africa & LIDC & $1995,1996,1997,1998$ \\
\hline
\end{tabular}

\section{CInternational Monetary Fund. Not for Redistribution}

